\title{
Abstract
}

\section{On the Use and Abuse of Geopolitics ${ }^{\dagger}$}

Rainer E. Zimmermann ${ }^{1, *}$ and Thomas Zimmermann ${ }^{2}$

1 Faculty Studium Generale, University of Applied Sciences, D-80636 Munich, Germany; Clare Hall, Cambridge, Cambridge, UK

2 Bavarian School of Public Policy, D-80333 Munich, Germany; tzimmermann@hotmail.de

* Correspondence: rainer.zimmermann@hm.edu

† Presented at the IS4SI 2017 Summit DIGITALISATION FOR A SUSTAINABLE SOCIETY, Gothenburg, Sweden, 12-16 June 2017.

Published: 9 June 2017

Originally, geopolitics was a theory that intended to conceptualize strategic insight into the world-wide political action of Great Powers governing their foreign policies. Hence, it was essentially a product of the late colonialism. In the tradition of Spengler and Toynbee, organicistic theories of the state dominated at the time, and authors like Kjellén and Mackinder followed this line in principle, not without influence onto the further development in Europe including the First World War as well as the Second. In more recent time, the US-American policy in the sense of Kissinger and especially Brzezinski continued this conception in one way or another. In the meantime, mainly during the eighties of the twentieth century, authors like Agnew and Toal have introduced what is called "critical geopolitics" trying to reconcile constructivist as well as realistic approaches to political theory and liberate them from organicistic ingredients by introducing post-colonial and cultural aspects, respectively. Some consequences are discussed here in detail, with a particular view to present-day populism.

(C) 2017 by the authors. Licensee MDPI, Basel, Switzerland. This article is an open access article distributed under the terms and conditions of the Creative Commons Attribution (CC BY) license (http://creativecommons.org/licenses/by/4.0/). 